Tarih Kültür ve Sanat Araştırmaları Dergisi

Revue des Recherches en Histoire Culture et Art

مجلة البحوث التاريخية والثقافية والفنية
Vol. 6, No. 4, September 2017

Copyright (C) Karabuk University

http://kutaksam.karabuk.edu.tr

\title{
DOI: 10.7596/taksad.v6i4.1120
}

Citation: Karkina, S., Fajzrahmanova, L., \& Gluzman, A. (2017). Subject-Oriented Approach in the Professional Formation of the Future Music Teacher. Journal of History Culture and Art Research, 6(4), 10711077. doi:http://dx.doi.org/10.7596/taksad.v6i4.1120

\section{Subject-Oriented Approach in the Professional Formation of the Future Music Teacher}

\author{
Svetlana V. Karkina ${ }^{1}$, Lyalya T. Fajzrahmanova ${ }^{2}$ \\ Aleksandr V. Gluzman ${ }^{3}$
}

\begin{abstract}
The article deals with the possibilities of introducing a subject-oriented approach into the practice of professional education of the future music teacher. Particular attention is paid to the forms and methods used in this field, as well as to the conditions of the modern cultural environment, which allows for the free self-realization of the individual in accordance with his subject needs. Subject-oriented approach is the practice-oriented research. The study identified a number of the most significant components in the preparation of a music teacher, such as individual forms of studies and a number of special methods, which include the method of artistic associations, verbal "allegories", metaphors, the method of heuristic tasks for mastering creative activities. The openness of the musical and pedagogical system has great importance in its ability to respond to changes in the music and educational environment, which includes educational institutions and various cultural institutions: theaters, concert halls, orchestral and choir groups. All that conditions are necessary to ensure the possibility of creative self-realization and self-actualization of future music teachers.
\end{abstract}

Keywords: Subject-oriented approach, Pedagogy, Art, Music, Teacher.

\footnotetext{
${ }^{1}$ Kazan Federal University, Kazan, Tatarstan str., 2. E-mail: s.karkina@mail.ru

${ }^{2}$ Kazan Federal University, Kazan, Tatarstan str., 2.

${ }^{3}$ V. I. Vernadsky Crimean Federal University, Republic of Crimea, Sovetskaya Street, 9.
} 


\section{Introduction}

The development of pedagogical science in the field of musical education presupposes the strengthening of the role of the creative personality in art (Berlyanchik, 2009). The need for greater focus on strengthening individual, subjective-personal assessments and creative, spiritual, meaningful interpretations are due to the very essence of music. One of the leading trends in modern pedagogical science is a growing interest in the subject-oriented educational concepts.

The essence of the subject-oriented approach consists in "creation of conditions for free creative self-development of the personality in which her interests, hobbies and requirements are recognized self-valuable" (Karkina \& Fajzrahmanova, 2016). Studies of other humanitarian scientific fields, such as linguistics and literature, show that ensuring the free development of the individual is relevant on a global scale and characterizes the main trends in the development of world consciousness. According to literature research "The problem of free will is one of the most serious ones for the Western civilization as a whole" (Smyslova \& Khabibullina, 2011). This fact is indicative, because "The semantics of each national language develops the system of images, in which the cultural information is accumulated" (Galiullina et al., 2016).

The subject-oriented approach represents a promising direction in the development of modern pedagogical science (Borytko \& Mazkajlova, 2002), where the creative self-realization and self-development are studied as "the main requirements of modern education" (Khurmatullina \& Yachina, 2015). This context increases the significance of the concept the "self-education culture" (Akbarova et al., 2016) which determines the vector of the development of modern pedagogical science.

The analysis of the structural components of the system of musical and pedagogical education makes it possible to identify the possibilities of introducing a subject-oriented approach into the educational process, whose goal is to create pedagogical conditions for the creative development of the musician-teacher. To the components of a holistic pedagogical system is the purpose and content of education, the pedagogical process and the management structures of this process, as well as the forms of its organization. To the components of the whole pedagogical system is the purpose and content of education, the pedagogical process and the management structures of this process, as well as the forms of its organization. Other components are methods, technologies and training tools, teachers and students. The content includes general, basic and professional culture, the pedagogical process unites education and upbringing, and the participants of the pedagogical and student collectives are individual and collective subjects of the pedagogical process (Orlov, 1995). 
The purpose of musical and pedagogical education is the formation of a teacher-musician, his musical culture, adequate to the contemporary realities of the worldview and outlook of the teacher-musician, and therefore, in the development of a personality capable of comprehending the surrounding reality, his inner world, the diversity of problems of human existence through musical intonation. Thus, the goal as the determining factor in the development of the musical and pedagogical system can be represented in our study in the form of a multicomponent structure where the ideological, vocational and pedagogical and musical-objective levels of education are integrated. The goal forms and defines other components of education, primarily its content. It should correspond to the current level of scientific ideas about the world, reflect the humanistic principles of the democratic structure and development of the world community, should be at the level of the latest achievements of science and technology, high standards of culture and art.

The special place in the training of a musician-teacher is given to an individual form of studies, the purpose of which is to develop the creative musical and performing abilities of students. The individual form of studies creates priority opportunities for the subject-oriented approach in teaching, when it is possible to take into account the level of his musical abilities, his intellectual, emotional and other psychophysical characteristics (working capacity, health, level of intelligence and emotional responsiveness, artistic and creative abilities) (Maslow, 2006). At the same time, it is possible to plan the degree of complexity of assignments, the rate of mastering the educational material, and also influence the formation of the professional interests and needs of the student, his artistic taste. The form of individual lessons allows the teacher in a dialogue with the student in the process of musical and creative communication to create a special atmosphere of passion for musical art, facilitated by a bright pedagogical "show", carried out in the process of discussing and analyzing the interpretation of the performed composition, as well as motivating the learner to independent creative search, to reflexing, self-control and self-development. Different forms of music lessons allow the use of a variety of teaching methods and didactic means that meet the goals, objectives and content of education.

\section{Methods}

Methods of education are one of the most important categories of pedagogical science. Despite the fact that a significant number of methods have been singled out in pedagogical literature, as scholars note, there is no general approach to the definition of this concept in pedagogy. V. I. Andreev in his study cites various interpretations of this category: "Teaching 
methods are the ways teachers work and the students led by them, with the help of which the mastery of knowledge, skills and skills is achieved ..." (Andreev, 2005).

In the process of studying in the university, the most perspective methods are those aimed at developing thinking, intuition and other creative abilities of students, among these methods are called business game methods, heuristic methods (brainstorming, empathy, inversion), research method. Teachers, in order to increase the effectiveness of the learning process, apply methods of problem-based learning, where the teacher should not simply communicate the ready knowledge to students, but create a problem situation and lead them to its solution. Methods of education include methods: goal-setting, planning, organization, stimulation, relaxation, rationing, accounting, control, pedagogical analysis, correction; Methods of selfeducation and education of the individual in the collective include methods: goal-setting, selforganization, mobilization, relaxation, rationing, accounting, self-control, self-analysis, selfcorrection. In music education, general pedagogical methods and, at the same time, specific teaching methods aimed at developing emotional perception, artistic imagination, creative intuition and the musician's intellect are used.

One of the most important ways of creative development of students - future music teachers is their inclusion in various types of artistic and creative practice using methods that develop musical abilities, artistic thinking and intuition. These are include: the method of "rumorsshaped" education (development) students 'ideas' method - the creation of representation "model clear sound image" (assuming the mental, imaginary representation sounding image, its mental actualization before the implementation of the actual sound; intonational method shaped dive, emotional and semantic modeling, the method of "bulk of the game - of listening"; heuristic tasks for the development of creative activities ("pre-writing" of the elements of a musical fabric, essay about the musical plays "modeled" in the "set" of genres, musical improvisation, play / sight-reading and transposition; educational "editing" musical scores, interpretation of music, learning "review" performing interpretation).

The most important task in teaching a music teacher is to "establish harmony between word and music", which is manifested in the ability to "translate" the figurative meaning of an essay to verbal language. The solution of this didactic task is carried out in the process of working on the interpretation of the musical composition, when the "experienced" emotions find an adequate expression in the word. The search of the "correct" interpretation of the artistic image of a musical work helps the method of artistic associations, verbal "allegories", metaphors.

Methods are also used that integrate various types of musical activity, for example, the method of "conducting in the instrumental training of a music teacher", capable of "distracting 
from details and concentrating on the integrity of performance". The method of "historical and pedagogical analysis based on a holistic conceptual approach to the study of the history of music education" is applied in university education, it finds application in the process of historical and pedagogical preparation of the music teacher, in courses whose content is various aspects of the history of music education.

\section{Results and Discussion}

All these methods allow not only to introduce the student to the world of artistic culture, but also to take into account his individual characteristics and to ensure the activation of selfeducation and self-realization, the construction of an individual educational trajectory.

Accomplishing students to the best achievements of the world musical art with the help of modern didactic means allows not only to expand the educational "space", but also to make the "boundaries" of the pedagogical system open, which meets the modern concept of education. The openness of the musical and pedagogical system is a condition for its possible response to various changes taking place in the cultural community, in the music and educational environment. In scientific research, the environment is defined as the aggregate of various factors that influence nature, the person with his thinking and the corresponding objective world. Category environment is studied by scientists in various planes (social, economic, political-ideological, aesthetic, subject-spatial, environmental, cultural and educational).

For the education of a music teacher, a musical cultural space has a great educational and developmental significance, and in the modern world - a multicultural space, it includes the musical and educational environment of an educational institution, a city, a region where the activities of various cultural institutions (conservatory and other specialized musical and educational institutions, as well as the Philharmonic, the Opera House, the Union of Composers, the Symphony Orchestra, other chamber instrumental and choral compositions, national cultural centers, theaters and concert halls, museums with music-educational "lecture" programs); as well as the activities of telecommunications channels (the "Culture" channel, Tatarstan cultural TV programs), computer music programs.

The most important element of the pedagogical system is management. Under the management of educational activities in pedagogy is understood the management of the teacher, its direct impact on students, or management, implemented through various technical means (for example, computer programs), or self-management, which is carried out by the student in relation to himself. The aim of management, therefore, is to regulate the 
educational and cognitive activities, perform control functions, and implement the correction of the learning process of learning material. The management of students' educational activities, as disclosed in pedagogy, is an essential part of the didactic process. In this process, scientists state the cyclical nature, singling out various, interchangeable acts of pedagogical activity, characterized by the unity of teaching and learning, the substantive and procedural aspect of this process. Defining the pedagogical process as a system, scientists call it systemforming elements: the purpose and result of education, the activity of the teacher (teaching) and students (teaching or learning activity). The interaction of teachers and pupils in the learning process is defined as an essential characteristic of the pedagogical process taking place in any pedagogical system. The variable components of this process are management tools that include the content of the educational material, material means (visual, technical, textbooks, teaching aids, computer training programs), teaching methods (methods of teaching and learning), forms of organization of instruction (lecture, seminar and others), methods of monitoring and evaluating learning outcomes. Along with the direct management of educational activities, there is traditionally external management, which is manifested in the activities of external bodies of management of educational institutions (now the Ministry of Education and Science and its subordinate structures). The duties of external management bodies include the creation of conditions for the functioning of the pedagogical system and also control functions in relation to the results of educational activity, to the organization of the educational process, to the financial activities of the corresponding educational structures.

\section{Conclusion}

The study identified a number of the most significant components in the preparation of a music teacher, such as individual forms of studies and a number of special methods, which include the method of artistic associations, verbal "allegories", metaphors, the method of heuristic tasks for mastering creative activities and others. The openness of the musical and pedagogical system has great importance in its ability to respond to changes in the music and educational environment, which includes educational institutions and various cultural institutions: theaters, concert halls, orchestral and choir groups. All that conditions are necessary to ensure the possibility of creative self-realization and self-actualization of future music teachers.

\section{Acknowledgments}

The work is performed according to the Russian Government Program of Competitive Growth of Kazan Federal University. 


\section{References}

Akbarova, G. N.; Dyganova, E. A. \& Yavgildina, Z. M. (2016). The Technology of SelfEducation in Music Pedagogues' Professional Training. TOJDAC, November, Special Edition, 2233-2238.

Andreev, V. I. (2005). Pedagogika of High School. Innovazionno-prognosticheskiy kurs: uchebnoye posobiye. Kazan: Zentr innovazionnih tehnologiy.

Berlyanchik, M. M. (2009). Iskusstvo i lichnost. V 2 kn. Kn. 1. Problimi khudozhestvennogo obrazovaniya i muzikalnogo ispolnitelstva. Moscow.

Borytko, N. M. \& Mazkajlova, O. A. (2002). Stanovlenie subektnoj pozicii uchashhegosja v gumanitarnom prostranstve uroka. Volgograd: Izd-vo VGIPKRO.

Galiullina, D. Kh.; Zamaletdinov, R. R. \& Bolgarova, R. M. (2016). Comparison as the Way of Tatar and Russian World Picture Specifity Representation. International Journal of Humanities and Cultural Studies, Special Issue, August, 556-562.

Karkina, S. V. \& Fajzrahmanova, L. T. (2016). Tradition and Modern Experience of the Kazan Piano School in the Aspect of Subject-Oriented Approach. Turkish Online Journal of Design Art and Communication, 6, 2451-2456.

Khurmatullina, R. C. \& Yachina, N. P. (2015). Formation of Individual Creative Activity Style of a Prospective Music Teacher. Review of European Studies, 7(5), 231-236.

Maslow, A. (2006). Motivatziia i lichnost. SPb: Piter.

Orlov, A. B. (1995). Lichnost i sushchnost: vneshnee i vnutrennee Ia cheloveka. Voprosy psihologii, 2, 5-19.

Smyslova, E. V. \& Khabibullina, L. F. (2011). The problem of Free Will in "The Clockwork Testament or: Enderby's End” by A. Burgess. The Turkish Online Journal of Design, Art and Communication, 2626-2631. 